\title{
Conclusion to Part 1
}

As you know, it is not the habit of the Federal Council to bring charges through public statements, or rather to criticise policies and practices of third states. We are aware that this restraint of our authorities may nowadays contrast with the behaviour of other states-also neutral onesand that it is not understood everywhere. ${ }^{1}$

In a letter to the Christian Peace Service in October 1973, the deputy chief of the DPA reiterated the Swiss government's habitual unwillingness to take a stand on Portuguese colonialism. Despite the double challenge issued by AfroAsian leaders and Swiss civil society actors since the late 196os, the majority of Swiss foreign policymakers saw no need to deviate from their policy of noninterference. On the issue of national liberation in Southern Africa, their position contrasted markedly to that of other small Western European states. The governments of Sweden, Norway, Finland, Denmark, Ireland, and the Netherlands showed more openness on Third World issues and repeatedly criticised Portugal's colonial policy and white minority rule, although to varying extents.

How to explain these different foreign policy choices? Swiss foreign policymakers frequently referred to their economic relations with Portugal to justify Switzerland's non-committal stance. When it came to policymaking on Portuguese colonialism, the importance of Switzerland's EFTA ties went beyond bilateral economic interests. Bern set great store by these ties as they were an expression of Western European cooperation and solidarity. Apart from the Swiss government's unwillingness to affront a fellow EFTA member, its reluctance to consider adapting its foreign policy also stemmed from the fear that, once it responded to demands to take a stand on colonialism and cut its limited economic investments in Portuguese Africa, it would be forced to make similar concessions in Rhodesia and especially South Africa, where Swiss economic and financial interests were much more substantial. As the other small European states did not have significant economic interests in sub-Saharan Africa that might be endangered by tensions with the white minority regimes or by decolonisation, they had a relatively wide marge de manoeuvre and decided they could afford to be more outspoken. ${ }^{2}$

1 Letter from Michael Gelzer, deputy chief of the DPA, to the Christian Peace Service, 04.10.1973, SFA E2001E-01\#1987/78\#4651*.

2 Lorenzo Ferrari, "The European Community as an Opposer of the Portuguese Colonial Rule: Debates and Initiatives, 1970-1974" Afriche e Orienti 19:3 (2017), pp. 69-84, p. 77. 
The Swiss government's reluctance to risk annoying Lisbon and Pretoria with which it had enjoyed close relations for decades, also stemmed from a deep, often unacknowledged, distrust of the less well-known and thus more unpredictable African actors that wanted to change the way international relations worked. Most FPD officials were hesitant to recognise African liberation movements as belligerents on a par with the Portuguese colonial authorities. Their reluctance to adapt their foreign policy to a new form of conflict was strengthened by the widespread low opinion of Africans, and the apprehension, hardly ever voiced but nevertheless present, that Angola and Mozambique's future rulers might turn towards the Soviet Union. Bern's unease in dealing with African non-state actors was echoed, although to a lesser degree, in its relations with newly independent African governments. Swiss foreign policymakers were displeased with the latter's criticism of Swiss foreign policy, and, more generally, with the Third World political movement's demands to reorganise global economic and political relations, and downplayed them as a needless politicisation of technical issues.

The national and international debates surrounding Switzerland's foreign policy in Southern Africa boiled down to questions of racial equality and justice in North-South relations and were therefore increasingly discussed in moral terms. Against this background, the Swiss government's insistence on its special role as a neutral state that was not part of the UN was met with decreasing sympathy, especially as neutral Sweden was one of Western Europe's foremost champions of national liberation in Southern Africa. For many Afro-Asian leaders and Swiss civil society actors, Switzerland's political and economic elites were part of the imperialist North exploiting the global South. This criticism impaired the credibility and respectability of Switzerland's neutrality in the Third World and built up significant pressure on the Swiss government to improve its image in the global South. Its established instruments of good offices and humanitarian and development aid were of limited use to silence critical voices. In the highly politicised context of Southern Africa, aid, in particular, automatically appeared to either support the African populations and potentially undermine the settler regimes, or legitimise white minority rule and thereby weaken African nationalism. This ran contrary to the supposedly non-political nature of Switzerland's aid policy. Swiss foreign policymakers had no coherent strategy to deal with these challenges to their foreign policy in Southern Africa. Instead, they clung to their position, attempted to deflect criticism, and hoped that their problems in the region would somehow disappear. On the whole, ambassador Felix Schnyder's selfdeprecating statement during a courtesy call at the US Department of State in 
early 1974 that, "the Swiss traditionally avoid problems instead of solving them" was most apt. ${ }^{3}$

Even though domestic and international criticism did not lead to substantial Swiss policy changes in sub-Saharan Africa between 1967 and 1974, the debate about Switzerland's role in North-South relations in the international arena and within Swiss society caused some friction within the Swiss government and federal administration. A small number of diplomats and foreign policymakers were willing to take heed of the criticism and suggested adapting the country's foreign policy, while a majority focused on keeping the door closed and refusing all concessions that might impair Switzerland's political and financial relations with the white minority regimes. Disagreements arose mainly between the FPD and the Trade Division, and between the diplomatic representations in New York and Addis Ababa, and headquarters in Bern. While Swiss ambassadors in New York and Addis Ababa were attuned to Third World opinion and insisted that the disapproval of African governments needed to be taken seriously, representatives of the Trade Division and the Swiss embassy in Portugal claimed that it was essential not to antagonise Switzerland's EFTA partner. In Bern, the head of the FPD put great emphasis on the opinion of Swiss churches critical of racial oppression, while most DPA members were unwilling to reconsider Switzerland's policy in Southern Africa, and the DIO advocated some small gestures towards the population of the region.

In the end, the Swiss government was able to resist the pressure to change its Southern African policy because the major Western powers also refused to cut their political, economic, and military links with Portugal and South Africa. Although Afro-Asian states and a transnational solidarity network confronted the US, the UK, and the FRG with their perceived failure to support national liberation in Southern Africa, and differences over how to deal with Portuguese colonialism were debated at organisations such as the EEC and NATO, there was enough 'respectable company'4 for Bern to hold out. That is, until the April 1974 Carnation Revolution in Portugal initiated the process of decolonisation in Angola and Mozambique and solved some of the problems.

3 Cited in David Pfotenhauer, memorandum of conversation between Swiss ambassador Felix Schnyder accompanied by Olivier Exchaquet of the Swiss embassy in Washington, with Arthur A. Hartman, Assistant Secretary of European Affairs, 26.o2.1974, p. 1, NARA, RG 59,

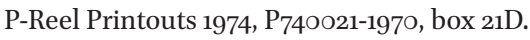

4 This term is borrowed from Norrie MacQueen, "Belated Decolonisation and UN Politics against the Backdrop of the Cold War. Portugal, Britain, and Guinea-Bissau's Proclamation of Independence", Journal of Cold War Studies 8:4 (2006), pp. 29-56. 